\title{
The Perceptions of Students and Teachers About The Use of Edutainment Instructional Media in Mathematics Learning
}

\author{
Riska Ayu Ardani \\ Yogyakarta State University \\ Magister of Mathematics Education Student \\ Yogyakarta, Indonesia \\ riska.ayu2016@student.uny.ac.id \\ Nilza Humaira Salsabila \\ Yogyakarta State University \\ Magister of Mathematics Education Student \\ Yogyakarta, Indonesia \\ nilza.humaira2016@student.uny.ac.id
}

\author{
Rhomiy Handican \\ Yogyakarta State University \\ Magister of Mathematics Education Student \\ Yogyakarta, Indonesia \\ rhomiy.handican2016@student.uny.ac.id \\ Wahyu Setyaningrum \\ Yogyakarta State University \\ Department of Mathematics Education \\ Yogyakarta, Indonesia \\ Wahyu_setyaningrum@uny.ac.id
}

\begin{abstract}
The purpose of this study was to describe the perception of students and teachers about the use of edutainment instructional media in mathematics learning. This study employed 223 students of junior high schools and 34 mathematics teachers. The data for this study were collected using a survey comprising questions in the research model. The results showed that the majority of students had positive perceptions to use edutainment instructional media in mathematics learning and they prefer games as edutainment instructional media rather than other types. Moreover, majority teachers had positive perceptions, but some others believed that edutainment instructional media can not facilitate mathematics learning better than the teacher.
\end{abstract}

Keywords- Edutainment Instructional Media, Mathematics Learning, Perception of students and teachers

\section{INTRODUCTION}

Technology is essential in teaching and learning mathematics; it influences the mathematics that is taught and enhances student learning [1]. Technology supports the value of knowledge in the abstract phase as well as the value of usability in the concrete phase of the mathematical process, it changes the language of mathematics, and causes a new quality of mathematical thinking [2]. The integration of technology in teaching becomes the challenge of 21 st century education [3] so it is necessary to make educational technologies must expand their forward thinking leadership and planning competencies so as to ensure effective use of new technologies[4].

There are many ways to accept the education challenges of the 21 st century. One of them is by developing an edutainment instructional media [5]. Edutainment instructional media can be distinguished into several types such as computer games, boards and videos, movies, music, websites, and multimedia [6]. Edutainment instructional media is perceived as a tool to improve the quality of teaching and learning $[7,8]$. The development of mathematics must be seen as a process happening in different phases. A possible model is a "two phase model, consisting of the phase of abstracting and the phase of concretising [2].

Edutainment is one of the learning bases that combine educational content into the entertainment context to facilitate learning [9]. Edutainment comes from the word education and entertainment. Instructional media based edutainment is to apply existing technology with modern entertainment as a medium of learning in the classroom [6]. Through edutainment students learn to use computer screens filled with graphics and colorful designs, thus convincing users that learning is exciting and entertaining [10] and the edutainment concept simply because it has a positive impact on the learning process and provides an enhanced learning experience [11].

The application of edutainment instructional media is less popular in education. It happens indicated that video game can not be accepted in education world [5], requires instructors with better knowledge and skills than narrative instruction, incurring higher costs [12], and the unique expertise that game designers have honed to a superfine edge is player engagement: the ability to keep people in their seats for hour after hour, day after day, at rapt attention, actively trying to reach new goals, shouting with glee at their successes, determined to overcome their failures, all the while begging for more [13]. 
Although we can find many applications and games that can help and facilitate students in understanding the concept of mathematics [14], very rarely encountered mathematics teachers who want to use instructional media in the classroom. it is a "question" of how to answer the challenges of $21 \mathrm{st}$ century education. This paper investigates student and teacher perceptions about the use of edutainment instructional media. Perception is an important factor in implementing technology in the classroom [7] because understanding students' perspectives can help teachers in integrating the technology in classroom, thereby can increase and improve the quality of the learning process [15], the integration of information and communication technologies can help revitalize teachers and students. This can help to improve and develop the quality of education by providing curricular support in difficult subject areas [16]. If students are skilled in technology mediated learning, they will be motivated and it will enhance their $21 \mathrm{st}$ century qualifications [17].

\section{METHOD}

\section{A. Research Design}

This study employed survey method in collecting qualitative and quantitative data. Data was analyzed using descriptive statistics. The data of students' and teachers' perception about the use of edutainment instructional media were gathered using written questionnaire. The questionnaire was used to answer research questions.

\section{B. Participants}

The subjects included three secondary school in Yogyakarta, Indonesia. The method of choosing the participants is random sampling, by selecting at random three schools in the region with lower category.
From these three schools, a sample of 223 students (109 males, 114 females) and 34 mathematics teachers ( 8 males, 26 females) participated in the study. Teachers (aged 24-41 years) selected are math teachers who have had teaching experience at different levels of educational units and with different teaching durations. The reason for choosing sample is that the time limitations and ease of access to conduct research.

\section{Instruments}

This research is a descriptive-qualitative research. We developed two questionnaires to gather information about students' and teachers' perception about the use of edutainment instructional media. The students' questionnaire contained two sections. Section I consist of five opened statements and section II consist of ten closed statements about students' perception. Same with teachers' questionnaire, section I consist of ten closed statements and section II consist of seven opened statements regarding teachers' perception. Questionnaires for students and teachers were developed using a 5-Likert scale in a closed questionnaire. The questionnaire has first validated the content (face and logic) by the expert.

This qustionnaires was developed based Technology Acceptance Model (TAM). TAM used as to measure user acceptance of computer technology. This model have high validity and useful to predicting technology usage $[18,19]$. Model (TAM) identifies two user beliefs: perceived usefulness and perceived ease of use, as the main determinants for individuals' behavioral intention to use information systems $[5,20]$.

This study modified the initial items of TAM by adding experience and preference variable. Variables using to measure the perceptions of students and teachers about the use of edutainment instructional media in mathematics learning in three secondary school in Yogyakarta, Indonesia. Sample of the

TABLE I.

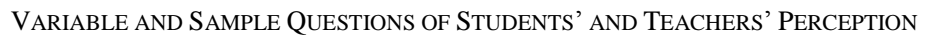

\begin{tabular}{|c|c|c|}
\hline Variables & Sample Questions Students' Perception & Sample Questions Teachers' Perception \\
\hline Experience & $\begin{array}{l}\text { 1. How do you think about mathematics learning? } \\
\text { 2. What types of media were used by teachers in the learning process } \\
\text { of mathematics? } \\
\text { 3. Have you ever used math-learning media such as games (super } \\
\text { mario, tetris, and harvest moon) in the learning process of } \\
\text { mathematics? }\end{array}$ & $\begin{array}{l}\text { 1. Learning in the classroom can be combined with entertainment } \\
\text { elements such as games, music, videos, multimedia, and more. } \\
\text { 2. Have you ever use educational games as edutainment instructional } \\
\text { media in teaching? } \\
\text { 3. How often do you make learning media for the teaching process? }\end{array}$ \\
\hline Preference & $\begin{array}{l}\text { 1. Determine the appropriate type of entertainment to be used as a } \\
\text { medium of mathematics learning? } \\
\text { 2. Should there be an element of entertainment in the learning process } \\
\text { of mathematics? } \\
\text { 3. Would you prefer to take math classes that use game media rather } \\
\text { than others (books, worksheet, presentation, and videos)? }\end{array}$ & $\begin{array}{l}\text { 1. If there are edutainment instructional media based on smartphone } \\
\text { games, do you think will be effectively used in the learning process? } \\
\text { 2. If there is a computer software that allows you to easily develop } \\
\text { educational games for learning, would you use it? } \\
\text { 3. Are you interested in training on creating educational games based } \\
\text { edutainment instructional media? }\end{array}$ \\
\hline Ease of Use & $\begin{array}{l}\text { 1. Do you think game is a suitable type of entertainment to be a } \\
\text { medium for learning math? } \\
\text { 2. Is it possible that math-learning media such as game can help you } \\
\text { to understand math material more easily? } \\
\text { 3. Do you agree though using entertainment media, you will not } \\
\text { understnad math material well? }\end{array}$ & $\begin{array}{l}\text { 1. Educational games can be used as instructional media in classroom } \\
\text { learning. } \\
\text { 2. Educational games can be used as learning media if developed or } \\
\text { created by teachers. } \\
\text { 3. Mathematics lesson material is not appropriate if combined with } \\
\text { educational media learning games }\end{array}$ \\
\hline Usefulness & $\begin{array}{l}\text { 1. Could the media of learning mathematics such as game increase } \\
\text { your motivation to learn mathematics? } \\
\text { 2. Could media of learning mathematics such as game keep you from } \\
\text { getting bored to learn mathematics? } \\
\text { 3. Does the math-learning media that inserts a game make you learn } \\
\text { math hardly? }\end{array}$ & $\begin{array}{l}\text { 1. The element of entertainment given during the lesson make students } \\
\text { can not focus on learning. } \\
\text { 2. Educational games can be a good learning medium to help students } \\
\text { learn if guided by the teacher } \\
\text { 3. Learning with educational games can hinder the learning process in } \\
\text { the classroom. }\end{array}$ \\
\hline
\end{tabular}


measures and the variables for students' and teachers' perception are shown in Table I.

\section{Analysis}

Data gathered from questionnaire are sorted and organized using MS.Excel. The data then analyzed descriptively including mean, modus, median of data.

\section{RESULTS AND DISCUSSION}

The aims of this study are 1) to determine students' perceptions about the use of edutainment instructional media in mathematics learning; and 2) to determine teachers' perceptions about the use of edutainment instructional media in mathematics learning. Based on these aims, the findings of this study are categorized under two main themes, namely: students's perceptions about the use of edutainment instructional media in mathematics learning and teachers' perceptions about the use of edutainment instructional media in mathematics learning.

\section{A. Students' Perceptions About The Use of Edutainment Instructional Media in Mathematics Learning.}

This study administers quantitative and qualitative data analysis technique. The questionnaires were tabulated to record the responses from each participant for each option of the questions and through student questionnaire obtained some data results are attached in the table below along with the discussion.

The 1st question was designed to determine the participants' perceptions about learning mathematics. The results can be seen in Table I.

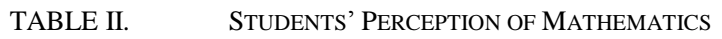

\begin{tabular}{|c|c|c|c|}
\hline \multicolumn{4}{|c|}{ How do you think about math lessons? } \\
\hline \multirow{5}{*}{ Difficultness } & Category & $N$ & Percentage \\
\hline & Hard & 64 & $58.18 \%$ \\
\hline & Medium & 37 & $33.64 \%$ \\
\hline & Easy & 9 & $8.18 \%$ \\
\hline & Total & 110 & \\
\hline \multirow{4}{*}{ Process } & Interesting & 41 & $66.13 \%$ \\
\hline & Half Interesting & 12 & $19.35 \%$ \\
\hline & Not Interesting & 9 & $14.52 \%$ \\
\hline & Total & 62 & \\
\hline \multirow{6}{*}{$\begin{array}{l}\text { Difficultness and } \\
\text { Process }\end{array}$} & Hard but Interesting & 26 & $50.98 \%$ \\
\hline & Hard and not interesting & 8 & $1.96 \%$ \\
\hline & Ordinary & 14 & $27.45 \%$ \\
\hline & Medium and Interesting & 1 & $15.69 \%$ \\
\hline & Easy and Interesting & 2 & 3.92 \\
\hline & Total & 51 & \\
\hline
\end{tabular}

In Table I obtained the data results from question section 1 number 1, how students' perception about mathematics. The result showed that most students think mathematics is a difficult subject to learn. The results of questionnaires by students in the table showed that $58.18 \%$ of 110 students said mathematics is a very difficult subject. This is also different from that found by Gafoor and Kurrukkan [21] which showed 20\% mathematical value as a very difficult subject, $54 \%$ reported moderate difficulty, with only $10 \%$ considered it an easy subject. This difference arised because there are differences in the learning culture of each country, the difference in the quality of education is also the main cause, and if seen there are differences in the rank of TIMSS Indonesia at the bottom level [22].

Nevertheless, the open questionnaire provided also yields another finding where there is potential for students' interest in mathematics. From the results of questionnaires found $66.13 \%$ of 62 students thought that mathematics is a fun subject. Furthermore, $50.98 \%$ of 51 students also revealed that mathematics is a difficult but fun subject. From the data obtained can be concluded that the perception of most students to mathematics is a difficult subject as well as fun. The results will explain that although math is difficult but it can be challenging for students if it is packed with interesting forms of learning.

The 2nd question was designed to determine the participants' perceptions about using edutainment instructional media as a teaching-learning tool in the classroom. Responses to this question are cited in the Table III

TABLE III. STUDENTS' PERCEPTION OF EDUTAINMENT INSTRUCTIONAL MEDIA

\begin{tabular}{|c|c|c|c|c|}
\hline \multirow{3}{*}{$\begin{array}{c}\text { Should there be an } \\
\text { element of entertainment } \\
\text { in the learning media } \\
\text { used? }\end{array}$} & \multicolumn{2}{|r|}{ Yes } & \multicolumn{2}{|r|}{ No } \\
\hline & $N$ & Percentage & $N$ & Percentage \\
\hline & 217 & $97.31 \%$ & 6 & $2.69 \%$ \\
\hline
\end{tabular}

Tabel III is derived from section 1 question number 2, should there be an element of entertainment in the learning media used. Through this question 217 or $97.31 \%$ of all students agree that learning in the classroom requires an element of entertainment. This shows that entertainment element in the learning process becomes the main attraction by students. The data is reinforced through a questionnaire in the 2nd section with a statement "media learning that insert entertainment can disturb the concentration of learning". As many as $5.16 \%$ of students disagree with the statement. It was found by Sarfo and Angsong [23] that students have strong perceptions that the computer can promote the first five principles of instruction for successful learning better than the teacher. Additionally, 54.26\% of students disagree with the statement in the 2nd section which states "although using media that inserts entertainment I still have trouble understanding math". It can be concluded that edutainment learning is required from the students' point of view.

TABLE IV. STUdENTS' REASONING To USE EdUTAINMENT Media FOR LEARNING MATHEMATICS

\begin{tabular}{|c|c|c|}
\hline Why there should be an element of entertainment in the learning media used? \\
\hline Argument & $\boldsymbol{N}$ & Percentage \\
\hline Help students to understand material & 58 & $26.01 \%$ \\
\hline Make students more focus on learning & 2 & $0.90 \%$ \\
\hline Make the learning situation is not boring & 112 & $46.22 \%$ \\
\hline Make the learning less seriously & 22 & $9.87 \%$ \\
\hline Make students more enthusiastic in learning & 8 & $3.59 \%$ \\
\hline
\end{tabular}


The need for entertainment element in learning for students, can be caused by various things. The results in table IV showed that most students feel by incorporating entertainment in learning makes the learning process in the classroom is not boring. In addition, students feel with the entertainment element can make them better understand the math and make the process of learning math more fun.

TABLE V. MEDIA USED IN LEARNING MATHEMATICS

\begin{tabular}{|c|c|c|}
\hline \multicolumn{3}{|c|}{ what type of media has ever been used in learning mathematics? } \\
\hline Type of Media & $\boldsymbol{N}$ & Percentage \\
\hline Book & 168 & $72.65 \%$ \\
\hline Worksheet & 78 & $34.98 \%$ \\
\hline Presentation & 75 & $33.63 \%$ \\
\hline Props & 20 & $8.97 \%$ \\
\hline Game & 7 & $3.14 \%$ \\
\hline Others & 8 & $3.59 \%$ \\
\hline
\end{tabular}

Mathematical learning process is boring for student because the media used by teachers in the classroom is less varied. Table $\mathrm{V}$ shows that teachers tend to use textbooks $(72.65 \%)$ in the learning process, followed by the use of worksheet $(34.98 \%)$ and teacher presentations. Teachers rarely use media that inserts entertainment (edutainment) in mathematics learning. Book have dominated the learning media used by teachers, this is due to the ease of obtaining and availability of existing books and is not a hassle to use. The next question explores how students' perceptions of what entertainment they choose in the learning process. The results of this statement can be seen in Table VI.

TABLE VI. The TyPe of ENTERTAINMENT Chosen to Be INSERTED IN THE INSTRUCTIONAL MEDIA

\begin{tabular}{|c|c|c|}
\hline \multicolumn{3}{|c|}{$\begin{array}{c}\text { which one the type of entertainment is chosen } \\
\text { to be inserted in the learning media ? }\end{array}$} \\
\hline Type of Edutainment & $\boldsymbol{N}$ & Percentage \\
\hline Music & 85 & $38.12 \%$ \\
\hline Video & 98 & $43.95 \%$ \\
\hline Comic & 15 & $6.73 \%$ \\
\hline Game & 146 & $65.47 \%$ \\
\hline Others & 4 & $1.79 \%$ \\
\hline
\end{tabular}

The less varied learning media of mathematics and the lack of elements of entertainment have an impact on the learning conditions in the classroom. So it needs an innovative media instructional such as edutainment instructional media. Table VI shows the result of question section 1 number 4 . It appears that most students $(65.47 \%)$ chose the game as an appropriate instructional medium used on mathematics subjects. This shows that the potential game to be a medium of learning is very high.

The large number of students who choose games as edutainment learning media, reinforced by the statement on the 2nd section of the questionnaire. The results can be seen in table VII. The overall data explains that the perception of the majority students on the use of edutainment instructional media especially games on learning mathematics was positive. Positive perception is expected to be a potential teacher to be utilized in improving the quality of teaching. This is similar to the research done by Bourgonjon, Valcke, Soetaert, and Schellens [5] that the main focus was on students' initial acceptance of video games in the classroom and Liton [17] showed that students demonstrated positive perception of technology adoption into their learning practices and it affects their learning situation through captivating and motivating into learning engagement more than traditional pedagogy.

TABle VII. Students' Perception on The Use of GAMe as Media FOR LEARNING MATHEMATICS

\begin{tabular}{|l|c|c|c|}
\hline \multicolumn{1}{|c|}{ Statement } & Agre $*$ & Doubtful & Disagree $^{*}$ \\
\hline $\begin{array}{l}\text { I prefer a class that uses game media } \\
\text { in learning mathematics than any } \\
\text { other medium }\end{array}$ & $45.29 \%$ & $30.04 \%$ & $24.66 \%$ \\
\hline $\begin{array}{l}\text { teachers should use the game as a } \\
\text { medium in the process of learning } \\
\text { mathematics in the classroom }\end{array}$ & $72.65 \%$ & $16.59 \%$ & $10.76 \%$ \\
\hline $\begin{array}{l}\text { game is a kind of entertainment that } \\
\text { is suitable to be a medium of } \\
\text { learning mathematics }\end{array}$ & $66.37 \%$ & $25.56 \%$ & $8.07 \%$ \\
\hline $\begin{array}{l}\text { media learning mathematics in the } \\
\text { form of game will help me in } \\
\text { comprehending math material }\end{array}$ & $56.05 \%$ & $33.63 \%$ & $10.31 \%$ \\
\hline $\begin{array}{l}\text { math learning media in game form } \\
\text { can increase motivation to learn } \\
\text { math }\end{array}$ & $68.16 \%$ & $26.46 \%$ & $5.38 \%$ \\
\hline $\begin{array}{l}\text { math learning media in the form of } \\
\text { games can reduce the boredom to } \\
\text { learn math }\end{array}$ & $79.82 \%$ & $14.80 \%$ & $5.38 \%$ \\
\hline $\begin{array}{l}\text { There is a scale simplicity between agree and very agree used and disagree and very disagree, the } \\
\text { simplification is done because of the similarity of measurement objectives. }\end{array}$ & \\
\hline
\end{tabular}

In the questionnaire also asked how students experiences using eduitainment instructional media with teachers in the classroom. The results of this question can be seen in Fig. 1.

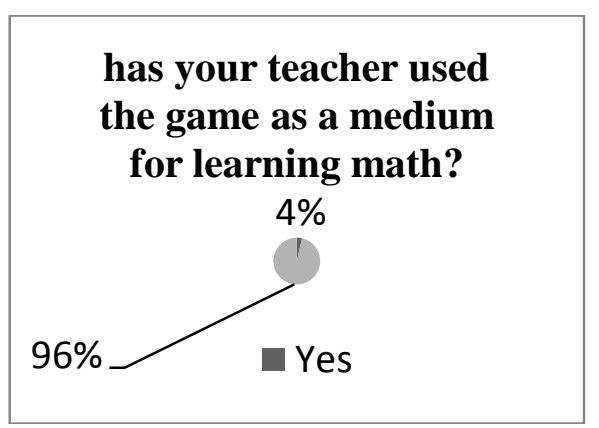

Fig. 1. The teachers' experience using edutainment instructional media

Fig. 1. reveals that most teachers $(96.41 \%)$ never used educational games as a medium for mathematics learning. The teacher's inability is caused by knowledge and skills and incurring higher costs [12], and the unique expertise that game designers have honed to a superfine edge is player engagement: the ability to keep people in their seats for hour after hour, day after day, at rapt attention, actively trying to reach new goals, shouting with glee at their successes, determined to overcome their failures, all the while begging for more [13].

In conclusion results of the study showed that the majority of students' perceptions of the edutainment instructional media 
in the form of games are positive, where $97.31 \%$ of students stated that there is an element of entertainment in the learning media used, $65.47 \%$ choose the game as an interesting entertainment to be used as learning media, $45.29 \%$ prefer classes that use edutainment instructional media in the form of games than traditional class, $72.65 \%$ of students want teachers to use instructional edutainment media in the form of games in the learning process, $66.37 \%$ of students want games that can help them to learn, $56.65 \%$ of students assume that games can help them to understand math, $68.16 \%$ of students believe edutainment game-shaped learning media can improve their learning motivation, and the last $79.82 \%$ of students assume edutainment instructional media in the form of games can eliminate boredom in the process of learning mathematics.

\section{B. Teachers' Perceptions About The Use of Edutainment Instructional Media in Mathematics Learning.}

In addition to describing the students' perceptions about the use of edutainment instructional media in mathematics learning, this study will describe how teachers' perceptions of the media. Wheter the media can be used in supporting mathematics learning in the classroom. So far the teachers have been trying to give a pleasant feel to the classroom, but many teachers also say that with the current technological developments students are demanding new innovations in every lesson or medium used.

The first question begins with the researchers want to know how often teachers create media for the learning process in the classroom. The analysis showed that the percentage of teachers who almost never make the media only reached $26.47 \%$, teachers who sometimes make learning media reach $44.12 \%$, and teachers who very often make the media reaches $29.41 \%$. Although the survey results show that teachers sometimes make media, but edutainment instructional media is still rarely developed by teachers. This is supported by the following data on how teachers experience using edutainment instructional media in teaching mathematics. The results can be seen in Fig. $2 .$.

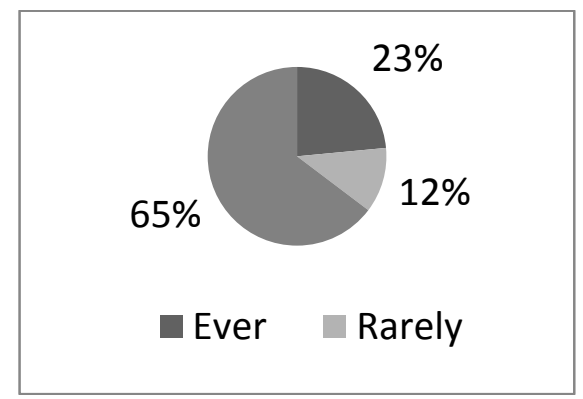

Fig. 2. The teachers' level on the use of edutainment instructional media

Results showed 34 respondents $64.70 \%$ of them stated that they never use edutainment instructional media in the form of games in teaching. The data is in accordance with previous data which explain that $96.41 \%$ of students claimed to have never been taught using edutainment instructional media. This is certainly a consideration of researchers to find out more why the teacher does not use edutainment learning media in the classroom.

The second question was given to the respondents about the necessity of entertainment element on the learning media used. The results can be seen in Fig. 3.

\section{should there be an element of entertainment in the instructional media used?}

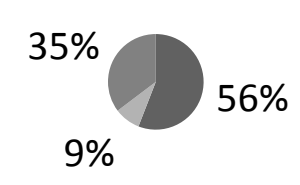

\section{Agree Doubtful Disagree}

Fig. 3. Teachers' perceptions on the use of edutainment instructional media

When teachers are faced with an option to use edutainment in the classroom learning process, many teachers give a positive impression. The results of the survey analysis in Fig. 3 show that teachers have a positive perception of learning media that contains elements of entertainment such as games, video, music, and comic. 34 teachers mostly gave the same reason that edutainment instructional media has great potential to be a classroom learning media because through edutainment instructional media it is suspected that students will become more focus on learning and keep students away from boredom.

After the researchers understood that the game is the most popular edutainment instructional media by the students, the researcher tries to dig up information about how the teacher perceives it through qualitative data which is further described as follows.

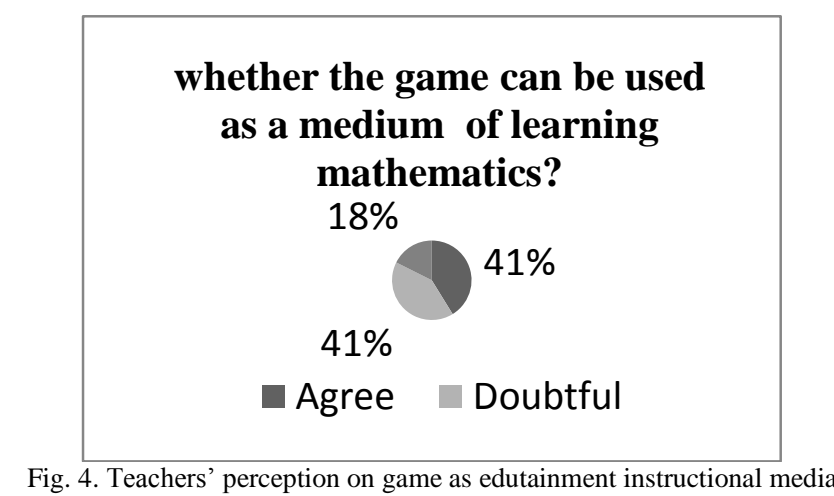

Fig. 4 shows that few teachers disagree with the use of games as a medium. But in other circumstances it is shown that both the agreeing and hesitant teachers have the same percentage. This indicates that teachers are not convinced by the use of class games that are caused by some of the following issues. It is also found by Gulbahar [16] that teachers are willing to use ICT resources and are aware of the existing potential. 
ICT could provide interactive media and good illustrations so that it would help students in mastering mathematical concepts [19]. Game can provide learning experiences to students with a variety of interesting animations. But they are facing problems in relation to accessibility to ICT resources and lack of inservice training opportunities [24]. Our results show that $94.12 \%$ of teachers are interested in training in developing edutainment media such as games and $97.06 \%$ will make their own if there is a software that is easy to use.

Table VIII shows some of the reasons expressed by teachers regarding the agree in the usage of instructional edutainment game as media.

TABLE VIII. TEACHERS' REASONING TO USE GAME AS EDUTAINMENT INSTRUCTIONAL MEDIA

\begin{tabular}{|l|l|}
\hline & \multicolumn{1}{|c|}{ Argument } \\
\hline 1. & $\begin{array}{l}\text { Can increase students' interest to learn mathematics which they } \\
\text { consider difficult material }\end{array}$ \\
\hline 2. & $\begin{array}{l}\text { Making it easier for students to learn anywhere and anytime so they can } \\
\text { train to learn independently }\end{array}$ \\
\hline 3. & $\begin{array}{l}\text { Students prefer learning that involves technology so that the game has } \\
\text { a good chance to be a medium of learning }\end{array}$ \\
\hline
\end{tabular}

While teachers who doubt that the game can be used as a medium of learning mathematics provides the following reasons. The results can be seen in Table IX.

TABLE IX. Teachers' Reasoning Why Hestitate to Use Game as EDUTAINMENT INSTRUCTIONAL MEDIA

\begin{tabular}{|c|l|}
\hline \multicolumn{2}{|c|}{ Argument } \\
\hline 1. & $\begin{array}{l}\text { Few students can not directly understand the material so they also need } \\
\text { guidance. }\end{array}$ \\
\hline 2. & $\begin{array}{l}\text { Teachers have difficulty monitoring whether the students have } \\
\text { implemented the learning process using the game or not. }\end{array}$ \\
\hline 3. & $\begin{array}{l}\text { Limitations of time owned by teachers and students to complete all } \\
\text { material. }\end{array}$ \\
\hline
\end{tabular}

Although the results of the study explain that most teachers have positive perceptions of the use of edutainment instructional media especially games in the classroom. the result of the research shows that from 34 teachers who become respondents, $64.75 \%$ never use edutainment instructional media in the learning process. Nevertheless, $55.90 \%$ of teachers assume that the element of entertainment is important in designing the media of learning mathematics, and $41.20 \%$ of teachers believe that the game can be used as a medium of learning mathematics. The reason is $41.2 \%$ teachers doubt if games will give a negative impact for students in learning process. $35,3 \%$ of teachers perceive that the element of entertainment that tucked can make students not focus on learning. In addition $32.40 \%$ stated that learning by using games can hamper the process of learning in the classroom. $50 \%$ of teachers feel hestitant because students will have difficulty understanding the material if using the game as a medium of learning. Basically these findings are similar to findings in which the result of the study conducted [23] indicate that the results of the study teacher. However, for the 4 aspects need further research
So we can conclude that there are some aspects that doubt teachers in using media edutainment media education in the classroom

1) Edutainment instructional media such as games is feared to have negative impact for students during the learning process of mathematics.

2) Edutainment instructional media such as games can make students not focus on the element of education and even more focus on the element of entertainment.

3) Edutainment instructional media based game can hamper the learning process, because it uses the supporting facilities in the form of electronic devices.

4) Edutainment instructional media based games is feared can make students difficult to understand the required teaching materials.

\section{CONCLUSIONS}

The conclusion of this study is to describe the perceptions of students and teachers in the use of edutainment instructional media in the process of learning mathematics. The results showed that students' perceptions of mathematics are negative, students still assume that mathematics is a difficult subject, but there are important things to note where students also assume that mathematics is a challenging subject. This fact can be used to adopt a change in the way of teaching and using technology so that teachers can take advantage of this potential.

In addition, the results of the study also showed that the majority of students' perceptions about the use of edutainment instructional media in the form of games are positive perceptions. From the teacher perception side, Most of mathematics teachers in this study have positive perception about the use of edutainment instructional media especially a game in the process of learning mathematics. Although the majority of teachers do not use edutainment instructional media in the teaching process, they believe that if there is an edutainment instructional media in the form of games because this media can improve the quality of learning and increase students' interest in learning mathematics. Therefore, the results might not necessarily to represent students' and teachers' perceptions because this study involved a small number of students and teachers in one district.

Although there are several aspects that doubt teachers in using media edutainment media education in the classroom, teachers need to consider the use of technology in the classroom. Therefore, further research is needed on these four aspects, if the aspect of doubt can be overcome, edutainment learning media becomes the most effective learning media used in the learning process of mathematics..

\section{REFERENCES}

[1] National Council Of Teachers Of Mathematics, "Principles and Standards for School Mathematics," Sch. Sci. Math., vol. 47, no. 8, pp. 868-279, 2000.

[2] H. Heugl, "The influence of technology in several roles of mathematics," Austrian Cent. Didact. Comput. Algebr., pp. 1-35, 2004. 
[3] Mukminan, “Tantangan Pendidikan di Abad 21," Semin. Nas. Teknol. Pendidik., pp. 0-10, 2014.

[4] R. Mayes, G. Natividad, and J. Spector, "Challenges for Educational Technologists in the 21 st Century," Educ. Sci., vol. 5, no. 3, pp. 221237, 2015 .

[5] J. Bourgonjon, M. Valcke, R. Soetaert, and T. Schellens, "Students' perceptions about the use of video games in the classroom," Comput. Educ., vol. 54, no. 4, pp. 1145-1156, 2010.

[6] O. V. Anikina and E. V. Yakimenko, "Edutainment as a Modern Technology of Education," Procedia - Soc. Behav. Sci., vol. 166, no. January 2015, pp. 475-479, 2015.

[7] G. Burrill, J. Allison, G. Breaux, S. Kastberg, K. Leatham, and W. Sanchez, "Handheld Graphing Technology in Secondary Mathematics: Research Findings and Implications for Classroom Practice," pp. 1-136, 2002.

[8] J. Olive, K. Makar, V. Hoyos, L. K. Kor, O. Kosheleva, and R. Sträßer, "Mathematical knowledge and practices resulting from access to digital technologies," in Mathematics Education and Technology-Rethinking the Terrain, 2010, pp. 133-177.

[9] A. Singhal and E. M. Rogers, "The entertainment-education strategy in communication campaigns," Public Commun. Campaign., pp. 343-356, 2001.

[10] Z. Okan, "Edutainment: Is learning at risk?," Br. J. Educ. Technol., vol. 34, no. 3, pp. 255-264, 2003.

[11] S. Nusair, B. Sharma, and G. Khan, "Edutainment for an Enhanced Learning Experience ( ELE),” pp. 3-5, 2012.

[12] H. Mat Zin and N. Z. Mohd Zain, "the Effects of Edutainment Towards Students' Achievements," Reg. Conf. Knowl. Integr. ICT 2010, vol. 129, p. $2865,2010$.

[13] M. Prensky, "Digital game-based learning," Comput. Entertain., vol. 1, no. 1, p. $21,2003$.

[14] E. Winarko, "Pembelajaran Matematika Berbasis TIK untuk Meningkatkan Literasi Matematika: Peluang dan Tantangan,” Semin. Nas. Mat. Univ. Negeri Yogyakarta, pp. 1-6, 2017.
[15] H. M. Selim, "An empirical investigation of student acceptance of course websites," Comput. Educ., vol. 40, no. 4, pp. 343-360, 2003.

[16] Y. Gulbahar and I. Guven, "A survey on ICT usage and the perceptions of social studies teachers in Turkey," Educ. Technol. Soc., vol. 11, no. 3, pp. 37-51, 2008.

[17] H. Liton, "Examining students' perception \&amp; efficacy of using technology in teaching English," Int. J. Educ. InformationTechnology, vol. 1, no. 1, pp. 11-19, 2015.

[18] P. Y. K. Chau, "An Empirical Assessment of a Modified Model Acceptance Technology,” vol. 13, no. 2, pp. 185-204, 2015.

[19] W. Setyaningrum, "Teachers ' Perception Towards ICT in Mathematics Class : A case study in Yogyakarta Secondary Schools," no. May, pp. 16-17, 2016.

[20] K. Mathieson, "Predicting User Intentions : Comparing the Technology Acceptance Model with the Theory of Planned Behavior Author ( $\mathrm{s}$ ): Kieran Mathieson Published by: INFORMS Stable URL: http://www.jstor.org/stable/23010882 REFERENCES Linked references are available o," Inf. Syst. Res., vol. 2, no. 3, pp. 173-191, 2016.

[21] K. A. Gafoor and A. Kurukkan, "Why High School Students Feel Mathematics Difficult? An Exploration of Affective Beliefs," UGC Spons. Natl. Semin. Pedagog. Teach. Educ. Trends Challenges, no. August, pp. 1-6, 2015.

[22] N. C. for E. S. NCES, "Highlights From TIMSS and TIMSS Advanced 2015," pp. 1-58, 2017.

[23] F. K. Sarfo and K. Ansong-Gyimah, "The perceptions of students, teachers, and educational officers in Ghana on the role of computer and the teacher in promoting the first five principles of instruction," Turkish Online J. Educ. Technol., vol. 9, no. 3, pp. 85-95, 2010.

[24] H. Stohl Drier, "Teaching and Learning Mathematics With Interactive Spreadsheets.," Sch. Sci. Math., vol. 101, no. 4, p. 170, 2001. 